\title{
Early Subclinical Biomarkers in Onco-Cardiology to Prevent Cardiac Death
}

Yajun Gu${ }^{1}$, Bumei Zhang ${ }^{2}$, Hongwei Fu ${ }^{1,3}$, Yichao Wang ${ }^{1}$ and Yunde Liu ${ }^{1 *}$

${ }^{1}$ School of Medical Laboratory, Tianjin Medical University, Tianjin, China

${ }^{2}$ Department of Family Planning, the Second Hospital of Tianjin Medical University, Tianjin, China

${ }^{3}$ Tianjin Medical University General Hospital, Tianjin, China

\begin{abstract}
Recent oncologic treatment has been associated with cardiovascular complications, such as hypertension, metabolic derangements, thrombosis, arrhythmia, and even cardiac death. Careful attention to detailed cardiac evaluation is required to optimize the anticancer treatment and prevent heart failure of patients undergoing chemoradiotherapy. Classical cardiovascular biomarkers like ANP, BNP, ProANP, NT-ProBNP, hsTnl, hsTnT, adropin, copeptin, and ET-1 are indicative of toxic effects in cancer patients with radiation, chemotherapy, and neoadjuvant treatment. Recently, miRNAs (i.e., miR-29, miR-146, miR-208, and miR-216) in the peripheral blood or exosomederived miRNAs are attractive as novel biomarkers for drug-induced cardiotoxicity due to their highly conserved sequence and stability in body fluids. The anticancer treatment could lead to detectable increases of miRNAs in the absence of traditional cardiac biomarkers or cardiac remodeling. Circulating cardiovascular biomarkers provide earlier detection of cardiotoxicity from cancer treatments before irreversible damage occurs. An increased understanding of the potential roles and mechanisms may help to reveal the crosstalk between cancer therapy and cardiac issues.
\end{abstract}

\section{Keywords: Biomarkers; Onco-cardiology; Cardiotoxicity}

Onco-cardiology, also known as cardio-oncology, is an interdiscipline subject in the field of cardiovascular care for cancer patients that have potential risk of developing heart disease due to certain oncologic drugs or radiation therapy (Table 1). Using a cloudbased health care database, Al-Kindi et al. [1] found that patients diagnosed with common cancers have an unexpectedly higher prevalence of Cardiovascular Disease (CVD) than general individuals. Overall, the prevalences were $33 \%$ for hematologic, $43 \%$ for lung, $17 \%$ for breast, $26 \%$ for colon, $35 \%$ for renal, and $26 \%$ for head and neck cancers.

The most common form of adverse effects is cardiomyopathy in regard to the use of anthracyclines as chemotherapeutic drugs. Compared with traditional chemotherapy, targeted cancer therapy is a novel strategy that has fewer cardiac complications on normal cells by inhibiting key molecules in signaling pathways involved in carcinogenesis and metastasis. However, either traditional or targeted chemotherapy can weaken the heart function or can even cause cardiac systolic dysfunction, cardiac ischemia, arrhythmias, pericarditis, and chemotherapy-induced repolarization abnormalities [2], underlined by deregulation of key signaling pathways in carcinogenesis (AMPK [3], RTKs-PDGFRs [4], etc.). Radiation-induced heart diseases (i.e., coronary artery disease, fibrotic changes to the valves, pericardium, and myocardium) have also been reported as the most common complications of cancer treatment strategies, especially in patients following radiation to the chest. The concurrent use of radiation and chemotherapy might have an increased risk of CVD in breast cancer $[5,6]$. Cancer patients with past cardiac history are usually more susceptible to the toxic effects of antineoplastic therapy and therefore are required to undergo realtime cardiovascular monitoring. For those without prior cardiovascular events, clinical oncologists may be more focused on diagnosis and treatment of neoplastic disease, rather than accessing side effects on the heart and vasculature.

Routine evaluation of cardiac function, even in asymptomatic individuals, is important as there is evidence that in patients developed Congestive Heart Failure (CHF) or asymptomatic decrease in Left Ventricular Ejection Fraction (LVEF) below 40\%, the discontinuation of long-term trastuzumab-based therapy leads to reversible improvement in cardiac function [7]. Assessment of drug-therapy-induced cardiotoxicity by conventional cardiovascular biomarkers (ANP, BNP, ProANP, NT-ProBNP, hsTnI, hsTnT, adropin, copeptin, and ET-1), circulating miRNAs (i.e., miR-29, miR-146, miR-208, and miR-216), or exosome-derived miRNAs might be considered in patients undergoing chemotherapy with cardiotoxic agents such as anthracyclines.

\section{Traditional Biomarkers for Cancer-therapy-related Cardiotoxicity}

ANP and BNP are secreted by the atria and ventricles in response to pressure overload when heart failure develops, respectively [8]. In addition to maintain excretion and salt/water balance, they promote diuresis, natriuresis, vasodilatation and repress the ReninAngiotensin-Aldosterone System (RAAS) $[9,10]$. Several studies have demonstrated that blood ANP and BNP levels are increased in patients with CVD [11,12]. Serum BNP levels are also shown to be elevated in cancer patients with the potential of CVD, suggesting that higher BNP may be indicative of progressive cardiotoxicity, especially with Anthracycline-Induced Cardiotoxicity (AIC) [13]. Feola et al. [14] found that the toxic effects following chemotherapy in breast cancer patients could be observed with plasma markers, the prospective study evaluated 53 patients with early breast cancer and candidate to adjuvant chemotherapy, in which blood BNP showed a positive trend of correlation with T3 LVEF.

Compared with ANP and BNP, their precursors ProANP and NTproBNP are more sensitive for evaluating early cardiac impairment. Plasma levels of proANP and NT-proBNP are inversely correlated

*Corresponding author: Yunde Liu, School of Medical Laboratory, Tianjin Medical University, Tianjin, China, Tel: +86 02260357239; E-mail: yundeliu@126.com

Received May 17, 2016; Accepted June 02, 2016; Published June 06, 2016

Citation: Yajun Gu, Zhang B, Fu H, Wang Y, Liu Y (2016) Early Subclinical Biomarkers in Onco-Cardiology to Prevent Cardiac Death. Cardiovasc Pharm Open Access 5: 183. doi:10.4172/2329-6607.1000183

Copyright: () 2016 Yajun Gu, et al. This is an open-access article distributed under the terms of the Creative Commons Attribution License, which permits unrestricted use, distribution, and reproduction in any medium, provided the original author and source are credited. 
Citation: Yajun Gu, Zhang B, Fu H, Wang Y, Liu Y (2016) Early Subclinical Biomarkers in Onco-Cardiology to Prevent Cardiac Death. Cardiovasc Pharm Open Access 5: 183. doi:10.4172/2329-6607.1000183

Page 2 of 6

\begin{tabular}{|c|c|c|c|c|c|c|}
\hline No. & Cancer & Treatment & Target & Complication & Dose-dependent & Ref \\
\hline 1 & Breast cancer & $\begin{array}{l}\text { Anthracycline (doxorubicin/ } \\
\text { adriamycin, epirubicin) }\end{array}$ & $\begin{array}{l}\text { Inhibition of DNA } \\
\text { polymerases \& DNA } \\
\text { fragmentation }\end{array}$ & $\begin{array}{l}\text { Arrhythmias, cardiac dysfunction, } \\
\text { congestive heart failure }\end{array}$ & $\begin{array}{l}\text { Doxorubicin: } \\
200-250 \mathrm{mg} / \mathrm{m}^{2} \\
\text { Epirubicin: } \\
500 \mathrm{mg} / \mathrm{m}^{2}\end{array}$ & {$[57,58]$} \\
\hline 2 & Leukemia & Mitoxantrone & $\begin{array}{c}\text { The anthracenedione } \\
\text { derivate }\end{array}$ & Cardiac systolic dysfunction & $40 \mathrm{mg} / \mathrm{m}^{2}$ & {$[59,60]$} \\
\hline 3 & Hematologic neoplasms & $\begin{array}{l}\text { Cyclophosphamide/ } \\
\text { cytarabine, cytoxan }\end{array}$ & Alkylating agent & $\begin{array}{l}\text { Cardiac systolic dysfunction, } \\
\text { pericarditis, cardiomyopathy }\end{array}$ & $\begin{array}{l}\text { Cyclophosphamide: } \\
180 \mathrm{mg} / \mathrm{kg}>4 \text { days }\end{array}$ & [61] \\
\hline 4 & $\begin{array}{l}\text { Gastrointestinal stromal } \\
\text { tumor, Chronic myeloid } \\
\text { leukemia, Renal cell } \\
\text { carcinoma }\end{array}$ & $\begin{array}{l}\text { Tyrosine kinase inhibitors } \\
\text { (imatinib, radotinib, dasatinib, } \\
\text { sunitinib, sorafenib, lapatinib, } \\
\text { erlotinib, nilotinib, crizotinib) }\end{array}$ & $\begin{array}{l}\text { Inhibition of hepatic } \\
\text { drug metabolism }\end{array}$ & $\begin{array}{l}\text { Cardiac systolic dysfunction, } \\
\text { arrhythmias, heart failure, } \\
\text { thrombophilia, pleural effusion }\end{array}$ & $\begin{array}{l}\text { Imatinib: } \\
400 \text { mg/day; } \\
\text { Radotinib: } \\
730 \text { mg/day; } \\
\text { Dasatinib: } \\
180 \text { mg/day; }\end{array}$ & [62-68] \\
\hline 5 & $\begin{array}{l}\text { Solid tumors, } \\
\text { Hematologic neoplasms }\end{array}$ & Interferon & $\begin{array}{l}\text { Inhibition of cancer } \\
\text { growing \& multiplying }\end{array}$ & $\begin{array}{l}\text { Cardiac systolic dysfunction, } \\
\text { cardiomyopathy }\end{array}$ & Dose-independent & [69] \\
\hline 6 & Breast cancer & Bevacizumab/avastin & $\begin{array}{l}\text { Inhibitor of vascular } \\
\text { endothelial growth } \\
\text { factor }\end{array}$ & $\begin{array}{l}\text { Cardiac systolic dysfunction, } \\
\text { hypertension, thrombosis, } \\
\text { cardiomyopathy, heart failure }\end{array}$ & $15 \mathrm{mg} / \mathrm{kg}$ & [70] \\
\hline 7 & $\begin{array}{l}\text { Neuroendocrine, } \\
\text { Lung, Prostate, Cervix, } \\
\text { Pancreatic, Hepatic, } \\
\text { Bladder, Biliary tumors }\end{array}$ & $\begin{array}{l}\text { Capecitabine, 5-fluorouracil, } \\
\text { gemcitabine }\end{array}$ & Antimetabolites & $\begin{array}{c}\text { Cardiac ischemia, coronary vascular } \\
\text { endothelial dysfunction and } \\
\text { coronary thrombosis }\end{array}$ & $\begin{array}{l}\text { Capecitabine: } \\
1000-2500 \mathrm{mg} / \mathrm{m}^{2} / \text { day }\end{array}$ & [71-73] \\
\hline 8 & Breast cancer & Taxanes (paclitaxel, docetaxel) & Antimicrotubule agents & $\begin{array}{c}\text { Acute myocardial infarction, } \\
\text { hypertension, deep vein thrombosis }\end{array}$ & Paclitaxel: 200 mg/m² & {$[74,75]$} \\
\hline 9 & Breast cancer & Everolimus & mTOR inhibitor & $\begin{array}{l}\text { Angina, hypertension, deep vein } \\
\text { thrombosis }\end{array}$ & $5-10 \mathrm{mg}$ & [76] \\
\hline 10 & Multiple myeloma & Bortezomib, carfilzomib & Proteasome inhibitor & Angina, hypertension, heart failure & $\begin{array}{c}\text { Bortezomib: } \\
1.3 \mathrm{mg} / \mathrm{m}^{2} \text { (4 days); }\end{array}$ & {$[77,78]$} \\
\hline 11 & $\begin{array}{l}\text { Ovarian germ cell tumor, } \\
\text { Hodgkin's disease }\end{array}$ & Bleomycin, etoposide, cisplatin & $\begin{array}{l}\text { Platinum-based } \\
\text { regimen }\end{array}$ & $\begin{array}{c}\text { Hypotension, pericarditis, acute } \\
\text { substernal chest pain, coronary } \\
\text { artery disease, myocardial ischemia, } \\
\text { myocardial infarction, cerebral } \\
\text { vascular accident, Raynaud's } \\
\text { phenomenon }\end{array}$ & $\begin{array}{c}\text { Bleomycin: } \\
5 \mathrm{mg} / \mathrm{m}^{2} \text { (3 days) }\end{array}$ & {$[79,80]$} \\
\hline 12 & $\begin{array}{l}\text { Ovarian, Oesophageal, } \\
\text { Small-cell lung cancer, } \\
\text { Melanoma. }\end{array}$ & Combretastatin & $\begin{array}{l}\text { Vascular disrupting } \\
\text { agents }\end{array}$ & $\begin{array}{l}\text { Acute myocardial infarction, } \\
\text { hypertension, angina }\end{array}$ & $36-54 \mathrm{mg} / \mathrm{m}^{2}$ & [81] \\
\hline 13 & Non-Hodgkin lymphoma & $\begin{array}{l}\text { Vinblastine, vincristine, } \\
\text { vinorelbine }\end{array}$ & Vinca alkaloids & $\begin{array}{l}\text { Myocardial ischemia, vaso-occlusive } \\
\text { complications, myocardial infarction }\end{array}$ & $\begin{array}{l}\text { Vinblastine: } \\
1.4 \mathrm{mg} / \mathrm{m}^{2}\end{array}$ & {$[82,83]$} \\
\hline 14 & $\begin{array}{c}\text { Breast, Colorectal, } \\
\text { Non-small-cell lung, } \\
\text { Glioblastoma, Renal cell, } \\
\text { Ovarian, Cervical cancer }\end{array}$ & $\begin{array}{l}\text { Trastuzumab/herceptin, } \\
\text { bevacizumab, rituximab }\end{array}$ & Monoclonal antibodies & $\begin{array}{l}\text { Cardiac ischemia, cardiac systolic } \\
\text { dysfunction, cardiomyopathy, heart } \\
\text { failure }\end{array}$ & $\begin{array}{c}\text { Trastuzumab: } \\
\text { Dose-independent; } \\
\text { bevacizumab: } \\
10 \mathrm{mg} / \mathrm{kg} ; \\
\text { Rituximab: } 375 \mathrm{mg} / \mathrm{m}^{2}\end{array}$ & [84-87] \\
\hline 15 & Hodgkin's disease & Radiotherapy & $\begin{array}{l}\text { Fibrous thickening of } \\
\text { the pericardium }\end{array}$ & $\begin{array}{l}\text { Pericarditis, pericardial effusion, } \\
\text { cardiac tamponade }\end{array}$ & $\begin{array}{l}\text { 30 42 Gy: 2-fold increase } \\
\text { in the risk of heart diseases }\end{array}$ & [88] \\
\hline
\end{tabular}

Table 1: Cardiovascular issues in cancer patients following chemoradiotherapy. 
with LVEF and the degree of increase in their concentrations correlates with the severity of cardiotoxic effects $[15,16]$. In a prospective study involved 40 patients with breast cancer, ProANP and NT-proBNP levels might be used as reliable and sensitive markers in predicting early cardiac impairment caused by epirubicin-based chemotherapy [17]. Another retrospective study was conducted on 52 patients treated with High-Dose Chemotherapy (HDC) for aggressive malignancy, consisting of breast cancer, lymphoma, myeloma, sarcoma, uterine cancer, small cell lung cancer, and acute myeloid leukemia. Their results demonstrated that persistently increased plasma NT-proBNP after HDC administration is strongly associated with development of subsequent cardiac dysfunction, which was important for identifying patients at risk of developing chemotherapy-induced cardiotoxicity [18].

Troponin is a complex of three contractile regulatory proteins, troponin $\mathrm{C}, \mathrm{T}$ and $\mathrm{I}$, which plays critical role in muscle contraction. Among them, Troponins $\mathrm{T}$ and I are only found in cardiac muscle, and they will spill into bloodstream and perform as diagnostic biomarkers, especially for acute coronary syndrome because of cardiac muscle injury [19]. Compared with troponins I, the T type has a larger molecular weight and a longer half-life in blood, and the latter one is more affected by renal dysfunction than troponin I [20-22]. According to the results of Kilickap et al. [23], elevated serum levels of cardiac troponin- $\mathrm{T}$ (cTnT) could be detected in early stages of patients treated with anthracycline, which is related to diastolic dysfunction of the left ventricle.

Beyond traditional detection of troponin $\mathrm{T}$ and $\mathrm{I}$, a high sensitive troponin assay is applicable to detect low abundance of circulating troponin in subclinical cardiovascular disorders [24]. In a prospective cohort of 19 women receiving anthracyclines and trastuzumab for HER2-positive breast cancer, the hsTnT level at 6 months was significantly higher in group $\mathrm{R}$ (LVEF reduction $\geq 5 \%$ ) than in group $\mathrm{N}$ (LVEF reduction $<5 \%$ ). The elevated hsTnT showed a possible ability to predict a subsequent reduction of LVEF, indicating trastuzumabinduced cardiotoxicity [25]. Other researchers described that plasma concentration of hsTnI correlates with the risk of trastuzumabinduced cardiotoxicity [26-28]. Omland et al. [29] discussed the differences between the roles of troponin $\mathrm{T}$ and $\mathrm{I}$ in the prediction of cardiotoxicity in patients with stable coronary artery disease. They found that hsTnI correlated moderately with hsTnT $(\mathrm{r}=0.44)$. Along with other parameters, the measurement of cardiac biomarkers such as NT-proBNP, hsTnT or hsTnI has been suggested to reflect and help monitor cardiac function during chemoratiotherapy [30,31].

Adropin is a recently identified peptide hormone that has been implicated in the regulation of cardiovascular regulation, energy homeostasis, and insulin resistance [32,33]. Aydin et al. [34] found that adropin was significantly increased in the endocardium, myocardium and serum in rats with Doxorubicin (DOX) treatment, which is a chemotherapeutic drug commonly used against various tumors [35]. In another study, also led by Aydin, suggested that the gradual increase in serum adropin could serve as an alternative to TnI for diagnosing Myocardial Infarction (MI) [36]. The cardiac failure associated with DOX-induced mitochondrial cardiomyopathy is the interference with oxidative phosphorylation and inhibition of ATP synthesis, which is related to adropin-energy metabolism and mitochondrial genome amplication [37,38]. Energy expenditure is mediated by adropin synthesized in the endocardium, myocardium, and epicardium [39]. Therefore, the upregulation of adropin after DOX exposure might indicate response of the cardiac endocardium and myocardium.
Copeptin is a 39 -amino acid peptide hormone that is involved in cardiovascular regulation and fluid homeostasis [40]. As the C-terminal part of pro-argnine vasopressin, the concentration of copeptin has been shown to increase early on acute cardiac events such as Acute Myocardial Infarction (AMI). There are several lines of evidence that combined testing of copeptin and troponin at presentation is a promising strategy in patients with suspected Acute Coronary Syndrome (ACS) and therefore aids in early and safe rule-out of MI [41-43]. Moreover, elevated copeptin levels were correlated with worse prognosis and higher risk of adverse effects after AMI, especially in patients who develop heart failure [44].

The Endothelin (ET) family consists of three structurally related peptides, including ET-1, ET-2, and ET-3, each containing 21 amino acids. ET-1 is a kind of vasoconstricting hormone that play critical role in cardiovascular homeostasis [45]. The plasma ET-1 rose progressively during DOX treatment of patients with breast cancer who subsequently developed Congestive Heart Failure (CHF) [46]. Elevated plasma ET concentrations in patients with CHF would be a predictor of cardiac death [47].

\section{Circulating miRNAs Shedding More Light on Onco- cardiology}

miRNAs are small, non-coding molecules, usually 22-24 nucleotides, that functions in translational repression and gene silencing. The expression levels of miRNAs in the peripheral blood are attractive as biomarkers of cardiotoxicity to chemoradiotherapy. As an ideal biomarker, the miRNA sequences are highly conserved among different species and are stable in human body fluids, such as plasma and serum, urine, saliva, amniotic fluid, and pleural fluid [48]. In addition, the miRNA levels can be easily detected in the laboratory by quantitative PCR and next-generation sequencing.

Several previous reports have demonstrated the great potential of miRNAs as clinical biomarkers for CVD [49,50]. Moreover, the cardio toxic effects on miRNAs expression in cancer patients were identified in few studies. Dinh et al. [51] reported that miR-29a decreased in circulation was associated with fibrosis of human heart with thoracic radiation therapy in patients with locally advanced non-small cell lung cancer. As an early biomarker of cardio adverse effects, circulating miR29a may provide a new way to predict symptomatic toxicities, thereby enabling dose adjustment before onset of eventual heart failure.

Holmgren et al. [52] evaluated the early and late effects of DOX admistration on the microRNAs expression profile, including miR34a, miR-34b, miR-187, miR-199a, miR-199b, miR-146a, miR-15b, miR-130a, miR-214, and miR-424. Several miRNAs with differentiated expression levels were identified by using pure cardiomyocyte cultures derived from human Embryonic Stem Cells (hESC), suggesting that miRNAs profiling may identify more promising markers in oncocardiology.

An in vivo study using rat model showed that plasma miR-208 levels increased significantly after isoproterenol-induced myocardial injury, which correlated with the concentration of TnI [53]. In a DOXinduced cardiotoxicity, miR-146a was shown to be upregulated in neonatal rat cardiac myocytes by targeting NRG-1/ErbB signalling. Inhibition of both ErbB2 and ErbB4 may be one of the reasons why those patients who received anti-ErbB2 antibody trastuzumab in combination with DOX suffer from congestive heart failure [54]. Another in vivo assay conducted by Suzzi et al. pointed out that the chronic myocardial toxicity induced by DOX in rats was associated with the modulation of microRNAs. Among them, miR-216b, which 
was significantly elevated before overt toxicity, has the potential of a genomic indicator of cardio events [55].

It has been reported that tumor-derived exosomes could transfer miRNAs to recipient cells, which mediates cancer progression and metastasis. Emanueli et al. [56] found that miRNAs, together with other acid nucleic molecules, proteins, and lipids can be released from exosomes. The plasma concentrations of exosomes and their cardiac miRNAs were positively correlated with hsTnI, which indicated a potential role for exosomes as novel biomarkers of myocardial injury.

\section{Summary}

Cardiac side effects of cancer therapy may vary from mild transient blood pressure to serious complications, including arrhythmias, myocarditis, pericarditis, MI, cardiac ischemia, cardiomyopathy, and CHF. Routine cardiac monitoring of cancer patients during radiation, chemotherapy, or neoadjuvant treatment is imperative for long-term prognosis and life quality of cancer survivors. Blood biomarkers provide non-invasive, practical and reliable methods to identify high risk of cancer patients in cardiac functions, especially asymptomatic events.

\section{Funding}

This work was supported by Tianjin City High School Science \& Technology Fund Planning Project (20140124), and Tianjin Natural Science Foundation (15JCQNJC11600, 15JCYBJC27400).

\section{References}

1. Al-Kindi SG, Oliveira GH (2016) Prevalence of Preexisting Cardiovascular Disease in Patients With Different Types of Cancer: The Unmet Need for OncoCardiology. Mayo Clin Proc 91: 81-83.

2. Hong RA, Limura T, Sumida KN, Eager RM (2010) Cardio-oncology/oncocardiology. Clin Cardiol 33: 733-737.

3. Lipovka Y, Konhilas JP (2015) AMP-Activated Protein Kinase Signalling in Cancer and Cardiac Hypertrophy. Cardiovasc Pharm Open Access 4.

4. Chen ZI, Ai DI (2016) Cardiotoxicity associated with targeted cancer therapies. Mol Clin Oncol 4: 675-681.

5. Hooning MJ, Botma A, Aleman BM, Baaijens MH, Bartelink H, et al. (2007) Long-term risk of cardiovascular disease in 10-year survivors of breast cancer. J Natl Cancer Inst 99: 365-375.

6. Eldabaje R, Le DL, Huang W, Yang LX (2015) Radiation-associated Cardiac Injury. Anticancer Res 35: 2487-2492.

7. Guarneri V, Lenihan DJ, Valero V, Durand JB, Broglio K, et al. (2006) Longterm cardiac tolerability of trastuzumab in metastatic breast cancer: the M.D. Anderson Cancer Center experience. J Clin Oncol. 24: 4107-4115.

8. Colucci WS, Elkayam U, Horton DP, Abraham WT, Bourge RC, et al. (2000) Intravenous nesiritide, a natriuretic peptide in the treatment of decompensated congestive heart failure. N Engl J Med 343: 246-253.

9. Beleigoli AM, Boersma E, Diniz Mde F, Vidigal PG, Lima-Costa MF, et al. (2013) C-reactive protein and B-type natriuretic peptide yield either a non-significant or a modest incremental value to traditional risk factors in predicting long-term overall mortality in older adults. PLoS One 8: e75809.

10. Adams KF Jr, Mathur VS, Gheorghiade M (2003) B-type natriuretic peptide: from bench to bedside. Am Heart J 145: S34-S46.

11. Mukoyama M, Nakao K, Saito Y, Ogawa Y, Hosoda K, et al. (1990) Increased human brain natriuretic peptide in congestive heart failure. $\mathrm{N}$ Engl J Med 323: 757-758

12. Stoupakis G, Klapholz M (2003) Natriuretic peptides: biochemistry, physiology, and therapeutic role in heart failure. Heart Dis 5: 215-223.

13. Wang YD, Chen SX, Ren LQ (2016) Serum B-type natriuretic peptide levels as a marker for anthracycline-induced cardiotoxicity. Oncol Lett 11: 3483-3492.
14. Feola M, Garrone O, Occelli M, Francini A, Biggi A, et al. (2011) Cardiotoxicity after anthracycline chemotherapy in breast carcinoma: effects on left ventricular ejection fraction, troponin I and brain natriuretic peptide. Int J Cardiol 148: 194198.

15. Selvais PL, Donckier JE, Robert A, Laloux O, van Linden F, et al. (1998) Cardiac natriuretic peptides for diagnosis and risk stratification in heart failure: influences of left ventricular dysfunction and coronary artery disease on cardiac hormonal activation. Eur J Clin Invest 28: 636-642.

16. Clerico A, lervasi G, Del Chicca MG, Emdin M, Maffei S, et al. (1998) Circulating levels of cardiac natriuretic peptides (ANP and BNP) measured by highly sensitive and specific immunoradiometric assays in normal subjects and in patients with different degrees of heart failure. J Endocrinol Invest 21: 170-179.

17. Kouloubinis A, Kaklamanis L, Ziras N, Sofroniadou S, Makaritsis K, et al (2007) ProANP and NT-proBNP levels to prospectively assess cardiac function in breast cancer patients treated with cardiotoxic chemotherapy. Int $\mathrm{J}$ Cardiol 122: 195-201.

18. Sandri MT, Salvatici M, Cardinale D, Zorzino L, Passerini R, et al. (2005) $\mathrm{N}$-terminal pro-B-type natriuretic peptide after high-dose chemotherapy: a marker predictive of cardiac dysfunction? Clin Chem 51: 1405-1410.

19. Apple FS, Wu AH, Mair J, Ravkilde J, Panteghini M, et al. (2005) Future biomarkers for detection of ischemia and risk stratification in acute coronary syndrome. Clin Chem 51: 810-824.

20. Tsutamoto T, Kawahara C, Yamaji M, Nishiyama K, Fujii M, et al. (2009) Relationship between renal function and serum cardiac troponin $\mathrm{T}$ in patients with chronic heart failure. Eur J Heart Fail 11: 653-658.

21. Tsutamoto T, Kawahara C, Nishiyama K, Yamaji M, Fujii M, et al. (2010) Prognostic role of highly sensitive cardiac troponin I in patients with systolic heart failure. Am Heart J 159: 63-67.

22. Fehr T, Knoflach A, Ammann P, Pei P, Binswanger U (2003) Differential use of cardiac troponin T versus I in hemodialysis patients. Clin Nephrol 59: 35-39.

23. Kilickap S, Barista I, Akgul E, Aytemir K, Aksoyek S, et al. (2005) cTnT can be a useful marker for early detection of anthracycline cardiotoxicity. Ann Oncol 16: $798-804$

24. DeFilippi CR, De Lemos JA, Christenson RH, Gottdiener JS, Kop WJ, et al. (2010) Association of serial measures of cardiac troponin T using a sensitive assay with incident heart failure and cardiovascular mortality in older adults. JAMA 304: 2494-2502.

25. Katsurada K, Ichida M, Sakuragi M, Takehara M, Hozumi Y, et al. (2014) Highsensitivity troponin $\mathrm{T}$ as a marker to predict cardiotoxicity in breast cancer patients with adjuvant trastuzumab therapy. Springerplus 3: 620 .

26. Sawaya H, Sebag IA, Plana JC, Januzzi JL, Ky B, et al. (2011) Early detection and prediction of cardiotoxicity in chemotherapy-treated patients. Am J Cardiol 107: $1375-1380$

27. Sawaya H, Sebag IA, Plana JC, Januzzi JL, Ky B, et al. (2012) Assessment of echocardiography and biomarkers for the extended prediction of cardiotoxicity in patients treated with anthracyclines, taxanes, and trastuzumab. Circ Cardiovasc Imaging 5: 596-603.

28. Fallah-Rad N, Walker JR, Wassef A, Lytwyn M, Bohonis S, et al. (2011) The utility of cardiac biomarkers, tissue velocity and strain imaging, and cardiac magnetic resonance imaging in predicting early left ventricular dysfunction in patients with human epidermal growth factor receptor II-positive breast cancer treated with adjuvant trastuzumab therapy. J Am Coll Cardiol 57: 2263-2270.

29. Omland T, Pfeffer MA, Solomon SD, de Lemos JA, Røsjø H, et al. (2013) Prognostic value of cardiac troponin I measured with a highly sensitive assay in patients with stable coronary artery disease. J Am Coll Cardiol 61: 1240-1249.

30. Suter TM, Ewer MS (2013) Cancer drugs and the heart: importance and management. Eur Heart J 34: 1102-1111.

31. Moreno R, Costa RG, Mazar RC, Silva MB, de Souza MG, et al. (2014) Evaluation of ultrasensitive cardiac Troponin I levels in patients with breast cancer during chemotherapy. Clin Chim Acta 428: 70-71.

32. Kumar KG, Trevaskis JL, Lam DD, Sutton GM, Koza RA, et al. (2008) Identication of adropin as a secreted factor linking dietary macronutrient intake with energy homeostasis and lipid metabolism. Cell Metab 8: 468-481.

33. Topuz M, Celik A, Aslantas T, Demir AK, Aydin S, et al. (2013) Plasma adropin levels predict endothelial dysfunction like ow-mediated dilatation in patients with type 2 diabetes mellitus. J Invest Med 61: 1161-1164. 
Citation: Yajun Gu, Zhang B, Fu H, Wang Y, Liu Y (2016) Early Subclinical Biomarkers in Onco-Cardiology to Prevent Cardiac Death. Cardiovasc Pharm Open Access 5: 183. doi:10.4172/2329-6607.1000183

Page 5 of 6

34. Aydin S, Eren MN, Kuloglu T, Aydin S, Yilmaz M, et al. (2015) Alteration of serum and cardiac tissue adropin, copeptin, irisin and TRPM2 expressions in DOX treated male rats. Biotech Histochem 90: 197-205.

35. Pommier $\mathrm{Y}$, Leo $\mathrm{E}$, Zhang $\mathrm{H}$, Marchand $\mathrm{C}$ (2010) DNA topoisomerases and their poisoning by anticancer and antibacterial drugs. Chem Biol 17: 421-433.

36. Aydin S, Kuloglu T, Aydin S, Kalayci M, Yilmaz M, et al. (2014) Elevated adropin: a candidate diagnostic marker for myocardial infarction in conjunction with troponin-I. Peptides 58: 91-97.

37. Wallace KB (2007) Adriamycin-induced interference with cardiac mitochondrial calcium homeostasis. Cardiovasc Toxicol 7: 101-107.

38. Lebrecht D, Walker UA (2007) Role of mtDNA lesions in anthracycline cardiotoxicity. Cardiovasc Toxicol 7: 108-113.

39. Aydin S, Kuloglu T, Aydin S, Eren MN, Yilmaz M, et al. (2013) Expression of adropin in rat brain, cerebellum, kidneys, heart, liver, and pancreas in streptozotocin-induced diabetes. Mol Cell Biochem 380: 73-81.

40. Dobsa L, Edozien KC (2013) Copeptin and its potential role in diagnosis and prognosis of various diseases. Biochem Med (Zagreb) 23: 172-190.

41. Reichlin T, Hochholzer W, Stelzig C, Laule K, Freidank H, et al. (2009) Incremental value of copeptin for rapid rule out of acute myocardial infarction. J Am Coll Cardiol 54: 60-68.

42. Keller T, Tzikas S, Zeller T, Czyz E, Lillpopp L, et al. (2010) Copeptin improves early diagnosis of acute myocardial infarction. J Am Coll Cardiol 55: 2096-2106.

43. Möckel M, Searle J (2014) Copeptin-marker of acute myocardial infarction. Curr Atheroscler Rep 16: 421.

44. Morawiec B, Kawecki D (2013) Copeptin: a new marker in cardiology. J Cardiovasc Med (Hagerstown) 14: 19-25.

45. Agapitov AV, Haynes WG (2002) Role of endothelin in cardiovascular disease. J Renin Angiotensin Aldosterone Syst 3: 1-15.

46. Yamashita J, Ogawa M, Shirakusa T (1995) Plasma endothelin-1 as a marker for doxorubicin cardiotoxicity. Int J Cancer 62: 542-547.

47. Galatius-Jensen S, Wroblewski H, Emmeluth C, Bie P, Haunsø S, et al. (1996) Plasma endothelin in congestive heart failure: a predictor of cardiac death? J Card Fail 2: 71-76.

48. Sandhu H, Maddock H (2014) Molecular basis of cancer-therapy-induced cardiotoxicity: introducing microRNA biomarkers for early assessment of subclinical myocardial injury. Clin Sci (Lond) 126: 377-400.

49. Li M, Zhang J (2015) Circulating MicroRNAs: Potential and Emerging Biomarkers for Diagnosis of Cardiovascular and Cerebrovascular Diseases. Biomed Res Int 2015: 730535.

50. Schulte C, Zeller T (2015) microRNA-based diagnostics and therapy in cardiovascular disease-Summing up the facts. Cardiovasc Diagn Ther 5: 1736.

51. Dinh TK, Fendler W, Chalubinska-Fendler J, Acharya SS, O'Leary C, et al. (2016) Circulating miR-29a and miR-150 correlate with delivered dose during thoracic radiation therapy for non-small cell lung cancer. Radiat Oncol 11: 61.

52. Holmgren G, Synnergren J, Andersson CX, Lindahl A, Sartipy P (2016) MicroRNAs as potential biomarkers for doxorubicin-induced cardiotoxicity. Toxicol In Vitro 34: 26-34

53. Ji X, Takahashi R, Hiura Y, Hirokawa G, Fukushima Y, et al. (2009) Plasma miR-208 as a biomarker of myocardial injury. Clin Chem 55: 1944-1949.

54. Horie T, Ono K, Nishi H, Nagao K, Kinoshita M, et al. (2010) Acute doxorubicin cardiotoxicity is associated with miR-146a-induced inhibition of the neuregulinErbB pathway. Cardiovasc Res 87: 656-664.

55. Vacchi-Suzzi C, Bauer Y, Berridge BR, Bongiovanni S, Gerrish K, et al. (2012) Perturbation of microRNAs in Rat Heart during Chronic Doxorubicin Treatment. PLoS One 7: e40395.

56. Emanueli C, Shearn Al, Laftah A, Fiorentino F, Reeves BC, et al. (2016) Coronary Artery-Bypass-Graft Surgery Increases the Plasma Concentration of Exosomes Carrying a Cargo of Cardiac MicroRNAs: An Example of Exosome Trafficking Out of the Human Heart with Potential for Cardiac Biomarker Discovery. PLoS One 11: e0154274.
57. Burridge PW, Li YF, Matsa E, Wu H, Ong SG, et al. (2016) Human induced pluripotent stem cell-derived cardiomyocytes recapitulate the predilection of breast cancer patients to doxorubicin-induced cardiotoxicity. Nat Med 22: 547-556.

58. Ayres LR, de Almeida Campos MS, de Oliveira Gozzo T, Martinez EZ, Ungari $A Q$, et al. (2015) Trastuzumab induced cardiotoxicity in HER2 positive breast cancer patients attended in a tertiary hospital. Int J Clin Pharm 37: 365-372.

59. Hagemeister F, Cabanillas F, Coleman M, Gregory SA, Zinzani PL (2005) The role of mitoxantrone in the treatment of indolent lymphomas. Oncologist 10: 150-159.

60. van Dalen EC, van der Pal HJ, Bakker PJ, Caron HN, Kremer LC (2004) Cumulative incidence and risk factors of mitoxantrone-induced cardiotoxicity in children: a systematic review. Eur J Cancer 40: 643-652.

61. Gottdiener JS, Appelbaum FR, Ferrans VJ, Deisseroth A, Ziegler J (1981) Cardiotoxicity associated with high-dose cyclophosphamide therapy. Arch Intern Med 141: 758-763.

62. Kim KW, Shinagare AB, Krajewski KM, Pyo J, Tirumani SH, et al. (2015) Fluid retention associated with imatinib treatment in patients with gastrointestinal stromal tumor:quantitative radiologic assessment and implications for management. Korean J Radiol 16: 304-313.

63. Kim SH, Menon H, Jootar S, Saikia T, Kwak JY, et al. (2014) Efficacy and safety of radotinib in chronic phase chronic myeloid leukemia patients with resistance or intolerance to BCR-ABL1 tyrosine kinase inhibitors. Haematologica 99: 1191-1196.

64. Johnson FM, Agrawal S, Burris H, Rosen L, Dhillon N, et al. (2010) Phase 1 pharmacokinetic and drug-interaction study of dasatinib in patients with advanced solid tumors. Cancer 116: 1582-1591.

65. Chu TF, Rupnick MA, Kerkela R, Dallabrida SM, Zurakowski D, et al. (2007) Cardiotoxicity associated with tyrosine kinase inhibitor sunitinib. Lancet 370 2011-2019.

66. Blanca AJ, Ruiz-Armenta MV, Zambrano S, Miguel-Carrasco JL, Arias JL, et al (2016) Inflammatory and fibrotic processes are involved in the cardiotoxic effect of sunitinib: Protective role of L-carnitine. Toxicol Lett 241: 9-18.

67. Pantaleo MA, Mandrioli A, Saponara M, Nannini M, Erente G, et al. (2012) Development of coronary artery stenosis in a patient with metastatic renal cell carcinoma treated with sorafenib. BMC Cancer 12: 231.

68. Doherty KR, Wappel RL, Talbert DR, Trusk PB, Moran DM, et al. (2013) Multiparameter in vitro toxicity testing of crizotinib, sunitinib, erlotinib, and nilotinib in human cardiomyocytes. Toxicol Appl Pharmacol 272: 245-255.

69. Sonnenblick M, Rosin A (1991) Cardiotoxicity of interferon. A review of 44 cases. Chest 99: 557-561.

70. Miller KD, Chap LI, Holmes FA, Cobleigh MA, Marcom PK, et al. (2005) Randomized phase III trial of capecitabine compared with bevacizumab plus capecitabine in patients with previously treated metastatic breast cancer. J Clin Oncol 23: 792-799.

71. Polk A, Vaage-Nilsen M, Vistisen K, Nielsen DL (2013) Cardiotoxicity in cancer patients treated with 5-fluorouracil or capecitabine: a systematic review of incidence, manifestations and predisposing factors. Cancer Treat Rev 39: 974 984

72. Kuropkat C, Griem K, Clark J, Rodriguez ER, Hutchinson J, et al. (1999) Severe cardiotoxicity during 5-fluorouracil chemotherapy: a case and literature report Am J Clin Oncol 22: 466-470.

73. Gruenberg J, Manivel JC, Gupta P, Dykoski R, Mesa H (2016) Fatal acute cardiac vasculopathy during cisplatin-gemcitabine-bevacizumab (CGB) chemotherapy for advanced urothelial carcinoma. J Infect Chemother 22: 112116.

74. Warm M, Kates R, Thomas A, Fischer T, Harbeck N (2009) Side-effects of preoperative epirubicin-paclitaxel therapy in primary breast cancer associated with tumor biology. Anticancer Res 29: 2675-2680.

75. van Boxtel W, Bulten BF, Mavinkurve-Groothuis AM, Bellersen L, Mandigers $\mathrm{CM}$, et al. (2015) New biomarkers for early detection of cardiotoxicity after treatment with docetaxel, doxorubicin and cyclophosphamide. Biomarkers 20: 143-148.

76. Morrow PK, Wulf GM, Ensor J, Booser DJ, Moore JA, et al. (2011) Phase II study of trastuzumab in combination with everolimus (RAD001) in patients with HER2-overexpressing metastatic breast cancer who progressed on trastuzumab-based therapy. J Clin Oncol 29: 3126-3132. 
Citation: Yajun Gu, Zhang B, Fu H, Wang Y, Liu Y (2016) Early Subclinical Biomarkers in Onco-Cardiology to Prevent Cardiac Death. Cardiovasc Pharm Open Access 5: 183. doi:10.4172/2329-6607.1000183

77. Bockorny M, Chakravarty S, Schulman P, Bockorny B, Bona R (2012) Severe heart failure after bortezomib treatment in a patient with multiple myeloma: a case report and review of the literature. Acta Haematol 128: 244-247.

78. Grandin EW, Ky B, Cornell RF, Carver J, Lenihan DJ (2015) Patterns of cardiac toxicity associated with irreversible proteasome inhibition in the treatment of multiple myeloma. J Card Fail 21: 138-144.

79. Didagelos M, Boutis A, Diamantopoulos N, Sotiriadou M, Fotiou C (2013) Bleomycin cardiotoxicity during chemotherapy for an ovarian germ cell tumor. Hippokratia 17: 187-188.

80. Porzig KJ, Portlock CS, Robertson A, Rosenberg SA (1978) Treatment of advanced Hodgkin's disease with B-CAVE following MOPP failure. Cancer 41: $1670-1675$.

81. Rustin GJ, Shreeves G, Nathan PD, Gaya A, Ganesan TS, et al. (2010) A Phase Ib trial of CA4P (combretastatin A-4 phosphate), carboplatin, and paclitaxel in patients with advanced cancer. Br J Cancer 102: 1355-1360.

82. Nakamae H, Tsumura K, Terada Y, Nakane T, Nakamae M, et al. (2005) Notable effects of angiotensin II receptor blocker, valsartan, on acute cardiotoxic changes after standard chemotherapy with cyclophosphamide, doxorubicin, vincristine, and prednisolone. Cancer 104: 2492-2498.
83. Lapeyre-Mestre M, Gregoire N, Bugat R, Montastruc JL (2004) Vinorelbinerelated cardiac events: a meta-analysis of randomized clinical trials. Fundam Clin Pharmacol 18: 97-105.

84. Dang C, Guo H, Naijta J, Yardley D, Marcom K, et al. (2016) Cardiac Outcomes of Patients Receiving Adjuvant Weekly Paclitaxel and Trastuzumab for NodeNegative, ERBB2-Positive Breast Cancer. JAMA Oncol 2: 29-36.

85. Ewer MS, Vooletich MT, Durand JB, Woods ML, Davis JR, et al. (2005) Reversibility of trastuzumab-related cardiotoxicity: new insights based on clinical course and response to medical treatment. J Clin Oncol 23: 7820-7826.

86. Economopoulou P, Kotsakis A, Kapiris I, Kentepozidis N (2015) Cancer therapy and cardiovascular risk: focus on bevacizumab. Cancer Manag Res 7: $133-143$.

87. Niitsu N, Khori M, Hayama M, Kajiwara K, Higashihara M, et al. (2005) Phase I/ll study of the rituximab-EPOCT regimen in combination with granulocyte colonystimulating factor in patients with relapsed or refractory follicular lymphoma including evaluation of its cardiotoxicity using B-type natriuretic peptide and troponin T levels. Clin Cancer Res 11: 697-702.

88. Schlitt A, Jordan K, Vordermark D, Schwamborn J, Langer T, et al. (2014) Cardiotoxicity and oncological treatments. Dtsch Arztebl Int 111: 161-168. 